\title{
Honoré de Balzac, Illusions perdues
}

\section{Anne-Marie Baron}

\section{(2) OpenEdition}

\section{Journals}

\section{Édition électronique}

URL : http://journals.openedition.org/studifrancesi/2194

DOI : 10.4000/studifrancesi.2194

ISSN : 2427-5856

\section{Éditeur}

Rosenberg \& Sellier

\section{Édition imprimée}

Date de publication : 1 avril 2014

Pagination : 159-160

ISSN : 0039-2944

\section{Référence électronique}

Anne-Marie Baron, «Honoré de Balzac, Illusions perdues », Studi Francesi [En ligne], 172 (LVIII | I) | 2014 mis en ligne le 01 avril 2014, consulté le 18 septembre 2020. URL : http://journals.openedition.org/ studifrancesi/2194; DOI : https://doi.org/10.4000/studifrancesi.2194

\section{Ce document a été généré automatiquement le 18 septembre 2020}

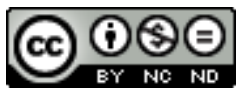

Studi Francesi è distribuita con Licenza Creative Commons Attribuzione - Non commerciale - Non opere derivate 4.0 Internazionale. 


\title{
Honoré de Balzac, Illusions perdues
}

\author{
Anne-Marie Baron
}

\section{RÉFÉRENCE}

HONORÉ DE BALZAC, Illusions perdues, édition de Jacques NOIRAY, Gallimard, «Folio classique», 2013, pp. 956.

1 Seule la mention «Folio classique» sur la couverture et sur la tranche distingue depuis 1994 cette collection de poche où sont présentées des éditions commentées des grands classiques de la littérature française et étrangère de l'Antiquité au début du xxe siècle par un spécialiste de l'auteur ou de la période, enrichies d'un dossier comportant une préface, une bibliographie, une chronologie, un appareil de notes fourni.

2 Jacques Noiray, grand dix-neuviémiste, balzacien éminent, présente Illusions perdues, «œuvre monstre», "premier roman total», composé de trois romans, rédigés séparément mais unis par la dynamique générale d'une action centrée sur le personnage de Lucien de Rubempré. Il suit l'édition «Furne corrigé» comme les éditeurs modernes et offre des notes substantielles sur la genèse et la réception de l'œuvre. La bibliographie, nécessairement limitée, est un peu aléatoire. Sa belle préface souligne que ce jeune homme fragile incarne «le drame d'une génération» désenchantée dans les premières années de la Restauration, celle-là même dont Balzac lui-même a fait partie. Elle montre que la spécificité du roman est sa construction fondée sur l'opposition Paris/province, symbolisée par la grande route Angoulême-Paris, lieu des voyages successifs aller-retour du héros. Les propres souvenirs de Balzac, combinés avec "un mythe général de la province», font d'Angoulême une ville emblématique, avec ses nobles d'un côté, la famille de Lucien de l'autre, marquée par la tache originelle d'une particule rêvée. Attiré par la capitale comme un papillon par la lumière, Lucien devient le type ou l'archétype de l'ambitieux de province qui se brûle les ailes. Alors que son beau-frère David s'engage à fond dans l'épopée du papier et la révolution de l'imprimerie, Lucien, entre le quartier latin, le grand monde et le milieu du journalisme et du théâtre, connaît à Paris l'échec progressif de toutes ses ambitions. 
J. Noiray précise pertinemment que l'aristocratie balzacienne «n'est pas un espace, mais un langage, un système de noms et de titres, un réseau d'allusions, de références, d'opinions» qui en font aux yeux de Lucien, comme sans doute de Balzac, «une superstructure idéale». Tandis que le journalisme est un pouvoir exorbitant et dangereux qui s'oppose à la morale idéale du Cénacle. Il montre que ces trois univers, vus du point de vue subjectif de Lucien, sont reconstitués par bribes dans une œuvre mosaïque qui se veut non seulement sociologique mais anthropologique.

3 Sur le plan littéraire pur, J. Noiray définit ce chef-d'œuvre par son mélange original des tons et des styles, qui fait affleurer le pathétique au cœur du processus tragique de la désillusion. Roman d'apprentissage dont le protagoniste n'apprend rien, voué qu'il est aux émotions, roman du pacte satanique avec Vautrin-Carlos Herrera plus que des amours féminines, c'est l'«œuvre capitale dans l'œuvre». À la fois «panorama pittoresque d'une société» et œuvre métaphysique dominée par la parabole de l'enfant perdu et le mythe de la chute des anges, ce roman continue à fasciner par la force du désir qu'incarne ce triste héros à la séduction inaltérable. 